\title{
Conexão Angola-Portugal: os dias de ponte aérea de um povo retornado
}

\author{
Pietro Gabriel dos Santos Pacheco ${ }^{1}$
}

\begin{abstract}
RESUMO: O fim da ditadura militar portuguesa, pela Revolução dos Cravos, anuncia o início de um novo período, tanto para Portugal quanto para Angola. A possibilidade de independência de uma colônia subjugada e o respiro de uma democracia que renascia. Entretanto, para uma parcela considerável de portugueses que ocupavam territórios coloniais, o momento era incerto e uma retirada de emergência precisou ser realizada. Cerca de meio milhão de portugueses são obrigados a abandonar suas casas em África e regressar para a Metrópole. É a partir deste momento que o presente trabalho está estruturado. Escolhemos usar a obra S.O.S Angola, da jornalista Rita Garcia, pois, encontramos relatos de pessoas que narraram suas experiências traumáticas e elas dialogam com as teorias de António Souza Ribeiro e Margarida Calafate Ribeiro e Stuart Hall, por exemplo.
\end{abstract}

PALAVRAS-CHAVE: Retornados; Literatura portuguesa; Literatura comparada.

\section{Connection Angola-Portugal: the days of flight service of a returned people}

\begin{abstract}
The end of the portuguese military regime, by the Revolução dos Cravos, announces the beginning of a new period for both Portugal and Angola. The possibility of independence from a subjugated colony and the breath of a democracy that was being reborn. However, for a considerable portion of the Portuguese who occupied colonial territories, the time was uncertain and an emergency withdrawal had to be carried out. About half a million Portuguese are forced to leave their homes in Africa and return to the metropolis. It is from this moment that the present work is structured. We chose to use the work S.O.S Angola, by the journalist Rita Garcia, because we found reports of people who narrated their traumatic experiences and they dialogue with the theories of António Souza Ribeiro and Margarida Calafate Ribeiro and Stuart Hall, for example.
\end{abstract}

KEYWORDS: Retornados; Portuguese literature; Comparative literature.

Quem constrói a casa não é quem a ergueu mas quem nela mora (Mia Couto).

A noção de África enquanto continente homogêneo limitou, por muito tempo, qualquer consideração, seriamente embasada, de modo científico e intelectual em relação ao continente africano e sua população. Essa ideia pré-concebida pelas nações europeias colonizadoras serviu de embasamento para diferenciações e classificações étnico-raciais, com repercussões politicoeconômicas que justificaram a exploração europeia, a qual era considerada uma atividade civilizatória.

Saindo do plano macro e caindo no micro, atentemos ao caso português que é antigo, diferente dos seus vizinhos ingleses e franceses, por exemplo, que voltaram seus olhos para a

\footnotetext{
${ }^{1}$ Mestre em Teoria da Literatura pela Pontifícia Universidade Católica do Rio Grande do Sul.
} 
África anos mais tarde. A primeira presença lusitana em território angolano ocorre em 1489, com a chegada de Diogo Cão à foz do Rio Zaire. A partir daí, estabelece-se na região contatos de cunho comercial, sobretudo em 1575, com a fundação da primeira povoação portuguesa, São Paulo de Assunção de Loanda, hoje capital de Angola.

O resultado disso é que, em pouco tempo, parte da costa africana é transformada em zona portuária. Visando manter o controle dos portos em África, são mandados alguns portugueses para serem os braços da Metrópole.

Anos mais tarde, com o "descobrimento" do Brasil em 1500, mais precisamente, em seu colonialismo de fato no ano de 1532, Portugal volta-se para o novo achado, que rapidamente se torna a menina de seus olhos, deixando parte do território africano em segundo plano.

As atenções, depois do Brasil, estão em Luanda, capital da colônia portuguesa em Angola, importante fonte de renda para os lusitanos, uma vez que a região se destaca como um dos maiores espaços de comércio escravagista. O início dessa atividade ocorre no ano de 1575. No momento, são recrutados para a tarefa parte dos portugueses que deixaram Portugal e mestiços, filhos de emigrados com angolanas - a miscigenação se dava, muitas vezes, pelo estupro. Logo, a formação social em Angola se dá através da união de brancos e negros, os mestiços, que se tornam os portadores de uma herança cultural mista, tanto europeia quanto africana. Tratava-se de um elo que comportava elementos culturais, políticos e econômicos favoráveis aos interesses da metrópole. Para o historiador Justin Pearce (2017):

$\mathrm{Na}$ falta de uma população de colonos numerosa, em Luanda, antes do início do século XX, as elites cultas formaram-se no seio da população mestiça e assimilada da região. Foi nessas comunidades e num grupo restrito de brancos com uma longa presença na colónia que começou a discussão de ideias anticoloniais (p. 55).

Esse grupo destacado acima se estabeleceu como parte de uma elite colonial devido ao papel desempenhado dentro do tráfico negreiro 2 . Era ela muitas vezes a encarregada das tarefas de captura e auxílio na exportação do negro como mercadoria - bastante valiosa e que dura, em termos, até 1850 , quando a Inglaterra intervém e proíbe a prática.

Com as mudanças político-sociais e econômicas que regem a história portuguesa e brasileira, o plano muda. O Brasil se torna "independente", visto que houve não uma ruptura, porém, uma troca de governantes. Portugal perde o domínio e decide se voltar para o filho

2 "Entre os séculos XVI e XIX, foram exportados de África para as Américas cerca de 8,3 milhões de escravos. Desses números, 6,1 milhões, apenas no século XVIII, representam três quartos do valor total". (ALEXANDRE, 1991, p. 293). 
deixado de lado.

Vale lembrar que nessa época, o mapa político muda, estamos no século XIX e as grandes revoluções do período exercem suas influências sobre a vida dos cidadãos europeus e americanos: o Iluminismo, as revoluções Industrial e Francesa, bem como as contribuições de Augusto Comte e Karl Marx, este último que vai exercer influência, sobretudo, no século seguinte.

Os impérios ${ }^{3}$, motivados por um desenvolvimento industrial desenfreado (não incluindo Portugal, que permanece predominantemente agrário), voltaram seus olhos para a África a partir do século XIX. Com a Conferência de Berlim (1884-1885) ${ }^{4}$, houve a intensificação da exploração territorial em busca de matérias-primas, um novo tipo de colonialismo que tem impacto na economia mundial ${ }^{5}$. Os avanços observados na história da Europa só seriam possíveis de continuar com a manutenção de materiais primários e secundários.

Na expansão dos grandes impérios ocidentais, o lucro e a perspectiva de mais lucro, foram, evidentemente, de enorme importância, como provam amplamente os atrativos das especiarias, açúcar, escravos, borracha, algodão, ópio, estanho, ouro e prata ao longo dos séculos (SAID, 2017, p. 44).

Se levarmos em consideração a disponibilidade de produtos, como madeira, carvão, algodão e petróleo, no continente, acharíamos uma carência deles. Da necessidade surge a possibilidade de exploração; os europeus veem na África e em partes da Ásia alvos fáceis. No caso do primeiro continente, objeto de nosso estudo, sobretudo em Angola, as atenções imperialistas serão quase que totais.

Mais do que a expropriação, temos que apontar o fator da diferença cultural e a fomentação das teorias darwinistas de superioridade, que irão provocar todo e qualquer tipo de pensamento e mentalidade sobre o ocidente e sobre o continente africano, principalmente os que envolvem questões físicas. Em outras palavras:

Nem o imperialismo, nem o colonialismo é um simples ato de acumulação e

\footnotetext{
3 “O império é uma relação, formal ou informal, em que um Estado controla a soberania política efetiva de outra sociedade política. Ele pode ser alcançado pela força, pela colaboração política, por dependência econômica, social ou cultural. O imperialismo é simplesmente o processo ou a política de estabelecer, ou manter um império" (DOYLE apud SAID 2017, p. 42).

4 "Esse encontro teve como pauta a retaliação do território africano. A noção europeia, de limites geopolíticos, bem como de propriedade privada da terra, foi imposta com cortes retilíneos sobre a terra de África, separando tribos e ocasionando uma mudança forçada e irreparável na organização social dos povos africanos" (RUCKERT, 2013, p. 78).

5 “O desenvolvimento tecnológico dependia de matérias-primas que, devido ao clima ou ao acaso geológico, seriam encontradas exclusiva ou profusamente em lugares remotos. O motor da combustão interna, criação típica do período que nos ocupa, dependia do petróleo e da borracha. [...] A borracha era um produto exclusivamente tropical, extraída com uma exploração atroz de nativos nas florestas equatoriais do Congo e da Amazônia [...]" (HOBSBAWN, 2011:107).
} 
aquisição. Ambos são sustentados e talvez impelidos por potentes formações ideológicas que incluem a noção de que certos territórios e povos precisam e imploram pela dominação, bem como formas de conhecimento filiadas à dominação: o vocabulário da cultura imperial oitentista clássica está repleto de palavras e conceitos como "raças servis" ou "inferiores", "povos subordinados", "dependência”, "expansão" e "autoridades” (SAID, 2017, p. 43).

Nesse sentido, a Conferência de Berlim foi a solução para os problemas industriais e econômicos imperiais, uma chave para a continuação do legado e soberania do europeu. Portugal, entretanto, viu nesse evento a possibilidade de perda da autonomia em partes da região que ocupava desde o século XVI. Com isso, desenvolveu um mapa representativo de sua pretensão de exercer soberania sobre os territórios de Angola e Moçambique. O denominado mapa Cor-de-rosa, entretanto, foi contestado pela Inglaterra e uma possível ameaça de guerra surgiu.

A única saída foi o recuo do projeto, pois os ingleses representavam, no período, a maior potência mundial. Como resultado, os republicanos aproveitaram-se da situação para mostrar a fraqueza tanto de D. Carlos, o rei, quanto dos princípios monárquicos.

Em outras palavras, diferente do que se aprende nos manuais escolares, essa conferência estruturou o mapa geográfico apenas nos casos franceses, britânicos, italianos e outros; para os portugueses, não houve um movimento de causa, mas sim de consequência. Para o pesquisador Boaventura de Sousa Santos (2003), ao contrário do colonialismo inglês, que "assentou-se num equilíbrio dinâmico entre colonialismo e capitalismo, o português assentou num desequilíbrio, igualmente dinâmico, entre um excesso de colonialismo e um déficit de capitalismo." (p. 25).

Concomitante a isso, a divisão proposta na Conferência de Berlim não respeitou os limites fronteiriços entre as etnias e grupos sociais existentes dentro de um mesmo espaço geográfico; ela estava ligada meramente aos interesses do colonizador, causando assim rupturas culturais e pertencimentos desencontrados. As relações entre a língua, religião e as atividades econômicas, por exemplo, foram desconsideradas, gerando, com isso, choques, entrecruzamentos culturais e, em alguns casos, também apagamentos socioculturais originários.

Com o colonialismo, pensa-se em uma política de expansão com caráter definitivo, visando um domínio político e jurídico da Metrópole sobre as populações nativas, além da exploração da mão de obra e dos recursos locais. No caso angolano, a ocupação, por parte das forças portuguesas, ocorreu a partir de pequenos núcleos litorâneos ${ }^{6}$, seguida da posse de

\footnotetext{
${ }^{6}$ Em Angola, a presença portuguesa terá quase que duplicado num espaço de cerca de 40 anos, passando de aproximadamente 13.000 colonos, em 1918, para mais de 58.000, em 1930. Todavia, nessa altura, não chegavam a representar $2 \%$ da população total (MENEZES, 2000, p. 54).
} 


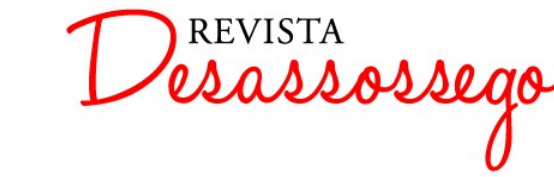

DESASSOSSEGO 20 - parte 2 |JUN/2019 | ISSN 2175-3180

DOI: http://dx.doi.org/10.11606/issn.2175-3180.v11i20p234-250

regiões interioranas com potencial comercial. Conforme João Paulo Henrique Pinto (2016), em sua dissertação de mestrado:

As tropas portuguesas, os missionários e os comerciantes avançaram sobre o interior de Angola e dominaram gradativamente o território nas chamadas "guerras de pacificação", que se estenderam até as primeiras décadas do século XX, variando o grau de penetração de acordo com as especificidades de cada região (p. 22).

Esse choque de cultura constitui-se como o processo inicial para a criação de uma nova identidade, em que se tem a influência do colonizador e certo apagamento ou exclusão da voz do colonizado. Criam-se, então, narrativas partidas da visão do português sobre o angolano, bem como toda a formação de estereótipos que permanecem até depois da conscientização do oprimido.

Vale ressaltar, ainda, que a distribuição territorial dos habitantes de Angola, como das demais colônias portuguesas, sempre foi uma questão administrativa difícil, tanto pela sua composição étnica, que englobava algumas tribos dentro de um mesmo espaço, quanto pelos fluxos migratórios que compõem sua história geográfica ${ }^{7}$.

Com a apropriação, vem a reprodução e criação de uma identidade colonial por meio da escrita - é esta que legitima e torna estereotipada a visão sobre o território africano. Isso leva ao borramento das narrativas originárias e à substituição dos elementos sígnicos produtores dos efeitos de sentido da ordem cotidiana, que passa a ser pautada pelos seguintes matizes: violência, objetalização e sectarização.

Seja por bem ou por mal, o fato é que o choque cultural entre colonizador e colonizado possibilitou a criação de códigos morais, éticos, bem como, e principalmente, linguísticos, que facilitaram a comunicação e uniram os diferentes agentes sociais que se encontravam ali localizados. Na sequência, Pinto (2016), continua:

A utilização de códigos culturais africanos e europeus pode ser percebida através de alguns elementos característicos presentes entre os filhos da terra, como a forma cadenciada de falar o português, a utilização de palavras em quimbundo para expressar hábitos cotidianos, o ritmo da música, a forma de dançar, a culinária, a indumentária, a religiosidade, os festejos populares e, principalmente, a existência de uma identidade própria dos filhos da terra, o que conferia historicidade própria ao grupo em questão (p. 23).

Ao adotar a linguagem do outro, o africano "civilizado" passa por uma imposição narrativa centralizante que desqualifica as suas narrativas de origem, o que o leva a pensar como

\footnotetext{
7 Para Pearce, Angola é um território caracterizado pela diversidade, tanto no plano geográfico como nas suas experiências históricas (PEARCE, 2017:44).
} 
o outro, entender os mecanismos que regem o pensamento político, econômico e social do europeu, bem como a estar ciente do contexto em que se encontra inserido. É a partir dessa apropriação que se desenvolve uma consciência que leva, mais tarde, a elite crioula a se mobilizar contra seu opressor.

A característica desse novo colonialismo é perceber o indivíduo enquanto ser social, enquadrado, integrado e aculturado dentro de algo maior. Nesse sentido, trata-se de embranquecer, ou aculturar o indivíduo angolano, e uma das formas de o fazer é através da marginalização da cultura dominada. É só a partir da ciência dessa posição que se adquire maior poder de intervenção; e o elemento fundamental para essa consciência é a língua. A pluralidade cultural pré-colonial existente agora é subtraída pelos códigos adotados.

À medida que portugueses chegavam ao território angolano, os mestiços, que outrora desenvolviam atividades importantes dentro da estrutura colonial, perdem seus postos e ocupam lugares menos privilegiados. Na nova ordem geográfica africana, promovida pela reunião dos colonialistas e acatada por Portugal, a elite crioula é realocada em outras atividades coloniais. E é a partir desse momento que os primeiros discursos identitários angolanos são realizados.

Visando buscar algo que os definisse, ainda no final do século XIX, muitos dos considerados letrados decidiram voltar-se para o quimbundo; entre eles encontrava-se Cordeiro da Matta. Essa preocupação se deu no sentido de valorizar alguns aspectos da cultura-mãe ou tradicional angolana. No prefácio de sua Cartilha para se aprender a ler Kimbundo, o autor convidava seus conterrâneos a se instruírem e aprender a ler, assim: "sejam gente para amanhã engrandecer a nossa terra há que lhes ensinar a nossa língua, língua dos nossos antepassados [...]. Aprendei a ler correctamente, filhos de Ngola Kiluanji Kia Danba! Lede! Lede!" (CORDEIRO DA MATTA apud OLIVEIRA, 1982, p. 209).

Além disso, Cordeiro da Matta estudou e resgatou elementos do Mbundo, entre eles ditos e contos populares, além de provérbios. Compilou tudo em outra obra, chamada de Filosofia Popular em provérbios angolenses, publicada no ano de 1891.

Essa busca por elementos primários não ocorreu de maneira crítica, uma vez que a língua do colonizador e os costumes foram mantidos por ele e seus seguidores. Historiadores afirmam que essa postura ocorreu apenas para que os filhos da terra se diferenciassem dos portugueses e dos angolanos.

Portugal, nesse momento, vivia um período de crise financeira gigantesco, o déficit 
econômico ${ }^{8}$ despertou um movimento que daria início à tentativa de revolta republicana. No mesmo ano da publicação de Cordeiro da Mata, tem-se o primeiro levante de políticos contrários ao monarquismo. Anos depois, em 5 de outubro de 1910, é anunciado no jornal Diário de Notícias a Proclamação da República.

Todavia, a ação encabeçada pela força militar não é bem-sucedida, mas não em sua maioria, e a crise permanece até 1928, quando surge António de Oliveira Salazar, um professor de economia da Universidade de Coimbra, ligado aos interesses da extrema direita. O sucesso de seus planos na política e finanças atribui-lhe certo prestígio e o converte em um "Salvador" necessário. Ao assumir o ministério, logo demonstra bastante habilidade, ganhando o prestígio necessário. De fato, como observa o professor A. H. de Oliveira Marques (2006), o orçamento apresentado por Salazar para 1928 e 1929 "previa um salto positivo que pôde ser efetivado e era o primeiro desde havia quinze anos" (p. 626).

O apoio da Igreja Católica e do Exército, seguidamente louvado por Salazar e pelos intelectuais de direita, possibilitou que o professor economista avançasse para outras esferas, iniciando, em 1929, discursos à nação envolvendo assuntos não-financeiros. Duas dessas falas se destinavam a pontos principais para o futuro do país. Acatado pela minoria influente e apoiado pelos militares, no ano seguinte Salazar decreta o Estado Novo, uma política com características ditatórias que resistiram até depois de sua morte.

Voltando para o caso luso-africano, a política implantada em Portugal escorreu para as colônias com a criação de um código intitulado Acto Colonial (Decreto-lei no 22:465), no qual ficava assegurado, nos artigos $35^{\circ}$ e $36^{\circ 9}$ que:

Art. $35^{\circ}$ Os regimes económicos das colónias são estabelecidos em harmonia com as necessidades do seu desenvolvimento, com a justa reciprocidade entre elas e os países vizinhos e com os direitos e legítimas conveniências da metrópole e do Império Colonial Português.

Art $36^{\circ}$ Pertence à metrópole, sem prejuízo da descentralização garantida, assegurar pelas suas decisões a conveniente posição dos interesses que, nos termos do artigo anterior, devem ser considerados em conjunto nos regimes económicos das colônias.

Segundo o documentado, o controle por parte da metrópole seria mais incisivo, gerando uma relação na qual apenas Portugal sairia ganhando, uma vez que grande parte daquilo que era produzido pelo filho (colonizado) deveria ser repassado para o pai. Como resultado, Angola

8 A crise de 1891 foi uma crise financeira porque as finanças do Estado e o sistema bancário entraram então em colapso. Depois, esta crise financeira tornou-se imediatamente uma crise económica, porque provocou uma estagnação do crescimento da riqueza (Santos, 2001, p. 258-259).

${ }^{9}$ Decreto-lei $\mathrm{n}^{\mathrm{o}}$ 22:465, também conhecido como Acto Colonial, disponível em: https://www.parlamento.pt/Parlamento/Documents/acto_colonial.pdf, visitado em: 18 de junho de 2019. 
deveria se dedicar ao cultivo e produção de matéria-prima necessários para o sustento da Metrópole. Porém, como isso afetava apenas a parcela camponesa da sociedade, pouco foi criticado.

Apesar dessa preocupação por uma cultura interpenetrada da elite angolana, o sentimento com a condição de colonizado inicia-se com os camponeses insatisfeitos com as medidas de Salazar em controlar o cultivo de alimentos. Pela região central ser importante na exportação de algodão, a prioridade se dá para o produto, "muito mais do que para as condições de sobrevivência dos trabalhadores que, sem acesso ao plantio, morrem de fome" (BIRMINGHAN in CHABAL, 2002:140).

Até a Segunda Guerra Mundial, a presença europeia em território africano era constante, porém, com o seu fim e com a queda das políticas ditatoriais, vem a expropriação do território, o que abre margem para a independência das colônias, sobretudo as localizadas no sul da África.

Entretanto, no caso português, ocorre o oposto: é mantida uma posição de neutralidade tanto durante quanto após o período destacado. Visando a continuar se apropriando dos recursos que provinham de suas colônias, o estado lusitano decide alterar o status dos territórios dominados, como observa Pearce:

Em 1951, Portugal alterou o estatuto de suas colônias para províncias ultramarinas, num esforço para evitar pressões internacionais no sentido de iniciar o processo de descolonização. Em 1954, o Estatuto do Indígena codificava um sistema de cidadania organizada em dois níveis, que concedia direitos a um conjunto restrito de assimilados e excluía a maioria indígena (PEARCE, 2017:57).

Com a Guerra Fria, vem a polarização política entre as duas maiores potências mundiais: Estados Unidos, com seu capitalismo, e a União Soviética, com seus ideais socialistas. As ideias do primeiro influenciaram na política colonialista portuguesa e, em contrapartida, em Angola e outras regiões africanas, penetraram as ideias do segundo.

Um fator importante para entender o nascimento dos movimentos nacionalistas é a saída de angolenses, filhos da classe comerciante, para Lisboa, sede metropolitana. Uma vez na Europa, o indivíduo é contaminado pelas diversas correntes estruturantes que regem a sociedade contemporânea, com suas políticas econômicas específicas.

A influência de uma política social com base no bem comum motivou membros jovens da elite a se reunirem para traçar um caminho rumo à independência do jugo português. A falta de unidade que marca esses grupos é notada quando a própria divisão territorial não respeita os limites étnicos existentes, obrigando os habitantes das tribos ao convívio de diferentes 


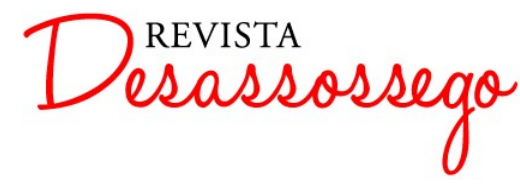

DESASSOSSEGO 20 - parte 2 |JUN/2019 | ISSN 2175-3180

DOI: http://dx.doi.org/10.11606/issn.2175-3180.v11i20p234-250

grupos culturais.

As demarcações oficiais de fronteiras (estabelecidas, através de acordos com antigos colonizadores europeus e respeitadas pelos governos das atuais nações independentes) não coincidem com as 'fronteiras étnicas', contribuindo para que diferentes povos transitem [...] de um lado para outro das fronteiras oficiais, aumentando ou diminuindo a população de certas regiões (MENEZES, 2000:98).

Ao regressarem à colônia, esses atores passam a compartilhar os mesmos códigos linguísticos e a identificarem em si um mesmo objetivo, a saber: questionar a presença portuguesa em território luso-africano.

A consciência de sua realidade se iniciou a partir das possibilidades de qualificação de estudantes que provinham de origem ultramarinas, tanto em Lisboa quanto em outras cidades portuguesas, sobretudo pelo benefício fornecido pela Casa dos Estudantes do Império. Uma vez em Portugal, a juventude intelectualizada, ao regressar, constitui o projeto V amos descobrir Angola ${ }^{10}$ e passa a externar sua indignação e deixar para trás a subalternidade provocada pelo colonialismo, quando muitos foram calados e reprimidos. É com a reunião dessa juventude que os movimentos contra o colonialismo se iniciam.

Essa pluralidade será refletida nos diversos tipos de grupos nacionalistas que, em nome de um ideal de mobilização anticolonial, irão plantar ideias de mobilização social em prol de uma Angola comandada para e por angolanos. Surgem dessas reuniões três grandes grupos: o MPLA $^{11}$, (Movimento Popular para a Libertação de Angola), o FNLA (Frente Nacional para a Libertação de Angola) ${ }^{12}$ e, uma década depois, a UNITA (União Nacional para a Independência Total de Angola $)^{13}$, que passam a combater a ameaça portuguesa, cada qual com seus métodos de guerrilha, porém contendo, nos três casos, um mesmo ideal.

A guerra era inevitável, e, em pouco tempo, o conflito atingiu proporções gigantescas. Para não voltar à condição de escravo, pegar em armas se tornava questão primordial. Para a

\footnotetext{
10 Em 1948, o movimento literário-cultural Vamos descobrir Angola constituiu-se num postulado e mesmo numa posição política de jovens intelectuais da época em relação à negação sistemática dos valores do povo angolano ou das diversas nações angolanas pelo colonialismo. A revista Mensagem, em seu segundo número, vai dar voz a esse postulado e ao Movimento dos novos intelectuais de Angola, como "um activo agrupamento literário em que militam alguns dos valores mais expressivos da moderníssima geração angolana” (SANTOS, 2015, p. 154).

11 Criado em 10 de dezembro de 1956, data que coincide com o lançamento do Manifesto de Viriato da Cruz, na província de Luanda, o qual teria resultado da unificação do Partido da Luta Unida dos Africanos de Angola (PLUAA) com outros grupos nacionalistas. (FRANCISCO, 2013, p. 129).

12 Fundada no ano de 1956, a sede do FNLA encontrava-se na "região do Norte Bacongo, região do antigo reino do Kongo, que se estendia do Noroeste de Angola até ao território da actual República Democrática do Congo. [...] Seus seguidores estavam ligados a comunidades instaladas em redor das missões protestantes, estabelecidas na região, a partir de meados do século XIX”' (PEARCE, 2017, p. 55/56).

${ }^{13}$ Criada em 13 de março de 1966 e situada no Planalto Central, sua origem "está ligada às missões, principalmente as protestantes" (PEARCE, 2017, p. 56).
} 
professora e pesquisadora Jane Tutikian (2006), como contra-ataque, a Metrópole toma as seguintes posições:

Portugal fecha, na metrópole, a Casa dos Estudantes do Império e a Associação dos escritores. Fecha toda a entidade cultural democrática, em Angola [...] Destrói as editoras e as gráficas. Proíbe a circulação da literatura angolana e leva para lá apenas os textos de qualidade inferior, comerciais, que não interessam à Europa. Enchem-se as prisões e o Tribunal Militar de Angola passa a um desempenho intenso. Renova-se a mentalidade de que a história angolana é a portuguesa [...]. Entretanto, o tempo, a consciência e, sobretudo, o sentimento já não são os mesmos e a guerrilha pela libertação ganha a colônia (p. 95).

Numa tentativa de controlar toda e qualquer rebelião e mobilização, Salazar decide intensificar sua presença nas colônias. Como extensão de seus olhos, ele ordena portugueses capacitados para controlar as ações nativas e, como parte de seus braços, coordena ações militares dentro do território. Por garantia, a partir de 1961, o ditador começa a enviar tropas para fortalecimento e contenção das rebeliões, como aponta o historiador A. H. de Oliveira Marques (2006):

Em fevereiro de 1961, algumas centenas de filiados do MPLA, passavam ao ataque armado de prisões, quartéis e estação emissora de Luanda. O governo, porém, conhecedor das linhas gerais da trama revolucionária e que, com fitos de prevenção, reforçara já as guarnições angolanas, enviando tropas da Metrópole (p. 705).

A guerra era necessária para alcançar a independência e encontrar a paz que Angola, durante séculos, não encontrou. E o ataque de Portugal uniu ainda mais os revoltosos. Um dos pontos de reunião dos guerrilheiros era a floresta de Mayombe, que se constitui por uma faixa que compreende parte da República Democrática do Congo, Angola e Gabão. As lutas anticoloniais saem do campo e chegam nas cidades a partir de 1971.

Em contrapartida à mobilização, temos a repressão. Em larga escala, multiplicavam-se os relatos dos horrores vividos pelos angolanos, narrados pelos próprios portugueses. No documento intitulado "Contra a Guerra Colonial: depoimentos de militares portugueses (19601974)", lemos os momentos de tensão existentes no período e praticados pelos antigos combatentes: desde morte a sangue frio até a violação de mulheres e crianças.

Tem-se feito muita barbaridade, valha-me Deus! Eu ouvi contar: espetam as cabeças dos pretos em paus compridos. Valha-me Deus! Nos primeiros dias andavam por ai, aos grupos, armados de revolveres e espingardas a caçar negros. O linchamento... (p. 12).

A repressão era grande, e a vulnerabilidade do povo angolano era expressiva. Se fazia necessário acabar com isso tudo. Não obstante, a construção de uma Angola renovada só seria possível com a expulsão daqueles que subjugaram e escravizaram os negros durante anos: era 
fundamental que a presença portuguesa fosse apagada. Com um denominador comum, esses movimentos encontravam elementos de identificação.

Ora, ao assumir a língua do colonizador, o indivíduo colonizado passa a apropriar-se de significados e, por meio dela, mobiliza-se o povo. A partir dessa consciência política, são criadas escolas ligadas aos movimentos independentistas, principalmente ao MPLA. Nesse sentido, a língua é unificadora dos grupos étnicos, mas não a finalizadora das diferenças existentes entre as tribos, o que resulta na criação de diversos grupos de resistência em um mesmo local.

Longe de somente validar o processo de construção pela escrita, estamos dialogando sobre as formas de apropriação da língua portuguesa ligadas a um grupo político dominante, nesse caso, o MPLA; que traz, de maneira positiva, elementos culturais e pré-colonialistas. Essas referências permitem que os leitores se identifiquem enquanto pertencentes a uma tradição e notem o poder de significação do hibridismo linguístico na Angola do século XX.

Essa apropriação da língua colonial, utilizada no processo de recriação da história angolana, vai permear todo o movimento de resistência e independência de Angola e das demais colônias portuguesas.

Junto com essa mobilização, vêm também fatores externos que enfraquecem, gradativamente, o poder de repressão de Portugal, sobretudo depois da morte de António Salazar e da sua sucessão por Marcello Caetano, que mantém, de maneira mascarada, os mesmos projetos políticos de seu antecessor.

A guerra estava ganha para a força de resistência nacionalista, e o futuro das colônias tornou-se uma questão política à medida que a visão ditatorial foi questionada pelos portugueses, sendo substituída por uma consciência mais democrática, que, timidamente, possibilitava visões alternativas sobre a presença portuguesa em Angola e demais territórios africanos.

Com a identificação vem a mobilização. Face às tensões coloniais, na Metrópole, o peso da mão de Salazar que caía sobre as colônias e as guerras, em um primeiro momento, após sua morte, foi amenizado. Entretanto, a cada passo rumo à democratização portuguesa, mais perto da independência esses grupos chegavam, e mais violentos esses conflitos se tornavam.

As ideias de democracia e libertação das colônias passam a motivar os grupos menos tradicionais, esses inspirados pelas teorias de um governo popular em que a voz de todos era ouvida. Em verdade, Portugal, com os cofres esvaziados e com uma política equivocadamente tardia, estava a contratempo da política mundial. A ascensão de Marcello Caetano, substituto de Salazar, é marcada por uma série de debates sobre os rumos de Portugal, principalmente 
sobre o colonialismo em África.

Com o fim da ditadura do Estado Novo $^{14}$ e a Revolução dos Cravos ${ }^{15}$, no ano de 1974, enfraquece, gradativamente, o motor que regia o colonialismo português.

A guerra findou com o saldo de 11 mil mortos e 30 mil deficientes, num total de treze $\operatorname{anos}^{16}$; e as forças que comandavam o exército português, que num primeiro momento expressavam apoio às políticas de colonialismo, com o fim da ditadura, passam a divergir em opiniões. Como resultado, em questão de quase um ano, uma população expressiva de portugueses retorna para Portugal - de mais de meio milhão de portugueses, cerca de 200 mil saíram apenas de Angola. Esse dado é apontado de maneira detalhada por Bruno Machado, que contabiliza o destino de parte dos regressados:

Entre os retornados, sabemos que 61\% são oriundos de Angola, 34\% de Moçambique e apenas 5\% do restante das colônias portuguesas, sendo que quase dois terços desses retornados nasceram em Portugal (63\%), embora esta proporção se inverta nas camadas mais jovens $-75 \%$ dos menores de 20 anos eram naturais das colônias (MACHADO, 2011, p. 70).

Se, por um lado, a ditadura estava finalizada e as colônias respiravam o ar da independência, por outro, a conexão entre Portugal e os retornados se tornava um tanto complicada. Trata-se de uma retirada rápida, alguns retornados nem assistidos foram.

Cada dia em Angola, já não mais colônia, era uma possibilidade de incerteza, não do destino, mas do caminho entre o passado que não existe mais e o futuro desconhecido. A visão dos africanos sobre os colonos portugueses e seus descendentes muda, e a força imperialista, que estava entranhada no modo de vida português, agora é reduzida a nada.

O novo governo na Metrópole e a visão de uma nova realidade motivam os nativos a lutarem pela sua liberdade. A guerra estava ganha para eles, e era apenas questão de tempo para que Angola ressurgisse sob o comando de líderes angolanos. Em poucos meses, o território angolano é transformado numa armadilha fatal para milhares de pessoas. Os portugueses que ali permaneceram, após 1974, encontravam-se abandonados com a retirada das Forças Armadas

\footnotetext{
14 A ditadura é instaurada em Portugal na sequência do golpe de 28 de maio de 1926, que derruba a I República (1910-1926). Assumindo, na primeira fase, uma feição militar (Ditadura Militar 1926-1933), a ditadura é constitucionalizada em 1933, autodenominando-se de Estado Novo. Um período definido como o de um estado forte e interventor em que, apesar dos equilíbrios constitucionais, se assiste a uma ampla concentração de poderes na figura de António Oliveira Salazar (REZOLA, 2017, p. 36).

15 A ação militar do 25 de abril começou por ser um golpe militar que, no próprio dia 25, se transforma numa "Revolução com levantamento militar - capitães que tinham participado na guerra colonial - e o levantamento popular e com uma dinâmica revolucionária animada e impulsionada pela classe operária e pelas massas populares e animada por objetivos de transformação profunda da sociedade" (CUNHAL apud GONÇALVES; PAREDES,2017, p. 102, p. 111).

16 Dados coletados por Mário Tomé, em 1980, e transcritos pela historiadora Silvia Correia, em um capítulo do livro Depois dos Cravos, de Leandro Pereira Gonçalves e Marçal de Menezes Paredes (2017, p. 90).
} 
e precisavam retornar à Metrópole.

Com a ameaça portuguesa neutralizada, abre-se espaço para a conquista do poder pela mão da elite nacionalista. Uma guerra entre os grupos de resistência pela hegemonia e união de Angola ocorre e o ambiente se torna cada vez mais hostil para os lusitanos que habitavam aquela região.

As antigas condições de supremacia europeia foram quebradas. Permanecer na região não era mais fator positivo para os portugueses. No período, diversos foram os relatos de mortes e desaparecimentos de brancos, como aponta Garcia (2017):

Ouvíamos falar de pessoas que desapareciam: umas porque se iam embora, outras porque desapareciam mesmo. Até à independência, o jornal Provincia de Angola publicava anúncios quase diários de pessoas que procuravam familiares em paradeiros incertos (p. 28).

O medo semeado pelos veículos de comunicação e presentificado em diversos conflitos pelo domínio do território colocou nos portugueses o pavor de serem as próximas vítimas. Uma das soluções encontradas para a retirada desses habitantes foi a organização de uma ponte aérea.

Numa primeira fase conseguia-se comprar passagens, visto que muitos acreditavam que, com a independência, se pudesse - criar uma terra mista e a mudança seria positiva para ambos, mas não foi. A conexão entre Angola e Portugal se torna um tanto complicada. Como dito acima, reiteramos que tratava-se de uma retirada rápida, alguns nem assistidos foram. Cada dia que se passava na antiga colônia era uma possibilidade de incerteza. Não do destino, mas do caminho entre o passado que não existe mais e o futuro desconhecido.

Com o agravamento da situação, veio o desespero, e esse sentimento compartilhado deu origem a filas cada vez mais longas à porta da delegação da TAP, companhia aérea, na baixa de Luanda. Segundo relato coletado por Rita Garcia, nas vésperas do início da ponte aérea, a oferta de lugares era quase insignificante para a procura que surgira. "Como seria de esperar, o pânico de ficar sem voo fez proliferar esquemas para conseguir um bilhete” (2017, p. 26).

Entre os meses de maio a novembro de 1975, período em que o projeto de retirada por meio de aviões aconteceu, cerca de 200 mil portugueses vindos de Angola chegaram a Portugal. Após essa data limite, todos aqueles que permanecessem no território estariam nas mãos dos angolanos.

Os portugueses presentes na antiga colônia perderam tudo e estavam assustados com o rumo que Angola tomava. Além disso, para muitos, o medo em relação ao seu destino era ainda pior, pois Portugal parecia uma terra distante e desconhecida, um futuro incerto. $\mathrm{O}$ título de retornado era desconhecido, pelo menos por parte da população, que vivera toda uma vida 
em África e se vira obrigada a viver numa terra distante e desconhecida.

Como muitos nunca pensaram em abandonar o território, malas foram doadas para aqueles que se adiantaram e, agora que elas estavam esgotadas no mercado, diz Garcia, "a única solução era mandar fazer uma trouxa a uma costureira" (2017, p. 13). Era preciso agir rapidamente, pois as notícias de desaparecimentos de portugueses ou morte de famílias inteiras eram comuns. Angola se tornava cada vez mais hostil.

Alguns escolheram o navio, entretanto, o avião pareceu uma melhor e mais rápida solução, além de mais segura. O número expressivo de retornados levou à precariedade do serviço prestado pela companhia aérea. Inúmeros são os casos de superlotação e falta de alimentos. Muitos pais de família, pensando no bem-estar de seus responsabilizados, mandaram mulheres e filhos para Portugal primeiro, migrando posteriormente. Angola toda estava ali.

Entre Maio e Novembro de 1975, o número de portugueses que queriam sair de Angola era tão grande que houve necessidade de criar uma Ponte Aérea especial. A operação foi um dos maiores salvamentos de civis feitos até então e levou para Lisboa 173.982 pessoas, para quem o sonho africano chegava ao fim e, com ele, os dias de uma vida mais livre e próspera do que a da Metrópole (GARCIA, 2017, p. 19).

No aeroporto, persistia o sentimento de incerteza. A população aglomerava-se desesperada para conseguir o bilhete. Garcia relata que era necessário acampar entre dois ou três dias em Luanda, a fim de conseguir um lugar no próximo voo.

O expressivo número de viagens resultou em uma crise de combustíveis em Angola, o que fez com que quase todos os aviões fossem obrigados a fazer escalas em outras cidades africanas, antes de prosseguir para o destino final: Portugal.

A tripulação percebeu a situação de emergência e mandou-os sentar sem pedir identificação a ninguém. Comunicou o incidente aos serviços de terra e explicou que só uma parte dos passageiros com lugar nesse voo poderia embarcar. Os restantes teriam de seguir mais tarde (GARCIA, 2017, p. 15).

Aqueles que deixavam o território podiam carregar consigo apenas cinco escudos por membro da família, e uma vida construída era reduzida a trinta quilos de bagagem. O passado se tornava apenas aquilo que era carregado, começava um período de raiva e revolta - cuja memória - nunca se perdeu.

Ao chegarem em Lisboa, sem qualquer bem ou capital, eles foram acolhidos por uma ação governamental que visava ajudar os antigos colonizadores, agora sem-terra, a se restabelecer e a ocupar seu lugar na nova terra lusitana. Todavia, essa política de auxílio não abraçou a todos, pois apenas aqueles que possuíam cargo administrativo ou de relevância nas antigas colônias africanas eram "agraciados por esse benefício". 


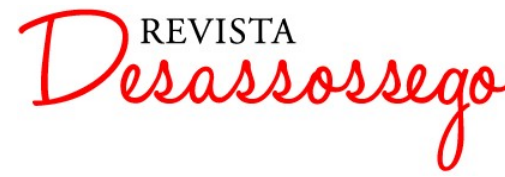

DESASSOSSEGO 20 - parte 2 |JUN/2019 | ISSN 2175-3180

DOI: http://dx.doi.org/10.11606/issn.2175-3180.v11i20p234-250

O Instituto de Apoio ao Retorno de Nacionais (IARN) foi um organismo criado para responder à problemática dos regressados das colônias africanas após a derrubada do Estado Novo, da instauração da democracia em Portugal e do início do processo de descolonização. Tratava-se de um órgão de ajuda para aqueles que durante anos viveram e ajudaram na economia portuguesa que, porém, agora, estavam destituídos daquele espaço que outrora era visto como seu. A posse da nacionalidade portuguesa para o retornado advinha, essencialmente, de duas vertentes: a primeira ligada ao ramo familiar e a segunda de um desempenho administrativo e funcional na antiga colônia.

Aqueles regressados que, em Lisboa, não dispunham de familiares capazes de lhes acolher, passaram algum tempo alojados em hotéis e espaços disponibilizados pelo IARN; entretanto, em muitos casos, essa temporada se limitava apenas ao tempo necessário para a arrecadação da bagagem que conseguiram pôr a salvo e tratarem de assuntos burocráticos. Apesar de ligados por um passado ou um currículo de serviços prestados, o modo de vida e de organização tornava-os diferentes. E isso era transparente tanto para os retornados, quanto para os portugueses que nunca deixaram sua terra, mas que viam no outro o diferente.

Além do sentimento de "não pertencimento", temos presente no coletivo dos retornados a tentativa de reconstrução partindo da memória. Perceber o diferente e sentir-se deslocado torna o processo de identificação muito mais penoso. Temos aí o processo de recorrência ao passado numa tentativa de encontrar-se, de maneira saudosista e melancólica.

A partir deste retorno, vem a tentativa de inclusão na nova democracia portuguesa e o trauma de deixar para trás uma vida construída em África. Ao chegarem em Lisboa, sem qualquer bem ou capital, os retornados foram acolhidos por uma ação governamental que visava ajudar os colonizadores, agora sem-terra, a se restabelecer e a ocupar seu lugar na nova terra lusitana. Todavia, essa política de auxílio não abraçou a todos, pois apenas quem possuía cargo administrativo ou de relevância nas antigas colônias africanas era "agraciado por esse benefício".

Temos aqui dois tipos de preconceito, o primeiro do antigo colonizador pelo colonizado, e um segundo, que recai sobre os regressados portugueses, detentores da cor local e criados fora da Metrópole. Esse, dificultando o processo de adaptação deles dentro do novo sistema político português.

Sabendo disso, recorremos aos professores António Souza Ribeiro e Margarida Calafate Ribeiro para entender o processo de reconfiguração e alocação desses retornados no sistema democrático português:

Memória e esquecimento, silêncio, trauma, recalcamento, mas também exaltação, imaginação, invenção e democracia portuguesa, nascida sobre uma 
revolução imaginada como pacífica, esquecendo assim, de um só golpe, todo o sangue de África - não parecia ser completada como um elemento essencial à construção da democracia (RIBEIRO; RIBEIRO, 2011, p. 30).

O processo de (re)contação dessas histórias, bem como a escolha de elementos a serem divulgados, além dos seus silenciamentos, compõem parte da história pós-colonial ${ }^{17}$ portuguesa. O resultado disso está na abertura de possibilidades de construções imagéticas que tornem o momento em questão totalmente, ou em grande, parte positivos.

Entretanto, esse processo está mudando, e a história vai sendo reescrita. Apesar dessa tradição de construção, a partir da oralidade, ser um tema recente, visto seu distanciamento curto, a literatura já ousou contar sobre esses retornados, bem como acerca de suas viagens e tentativas de recomeço. Como exemplo, destaco o seguinte excerto:

Quando o avião tomou altura houve dentro da cabina um silêncio fundo sobre a baía de Lourenço Marques, os subúrbios, as palhotas, as terras de cultivo, o mato que vi enquanto subíamos. Em silêncio, mas num silêncio ainda mais fundo, porque afinal já era uma mulher, voltei a chorar o que perdia e haveria de pagar. A dívida alheia que me caberia. Nunca entreguei a mensagem de que fui portadora. (FIGUEIREDO, 2011, p. 111).

O trecho, retirado do livro Caderno de Memórias Coloniais, da escritora Isabela Figueiredo, é um exemplo do papel que a literatura buscou ocupar enquanto linguagem representativa de um período traumático. Gritando, o silêncio amedronta todos aqueles que outrora construíram suas vidas em uma colônia e se viram obrigados a voltar para a terra que muitos sequer conheceram.

Além de Figueiredo, António Lobo Antunes, Dulce Maria Cardoso e outros retornados, ou participantes no processo de transição do colonialismo para a independência, buscaram, na ficção, uma forma de rememorar momentos da partida turbulenta e da chegada na metrópole. Os relatos trazidos por eles em sua maioria tangenciam a experiência de perda violenta de quase 500 mil portugueses reincorporados no processo democrático português.

Deixar para trás aquilo que um dia foi presente é perder um pouco de si, é apagar a memória e fazer morrer algo bom. Os objetos e suas lembranças se perdem em um território não mais seu, à medida que o novo atemoriza. O mar, nesse sentido, torna-se um meio de vislumbrar o que não existe, recorrer às memórias e trazer um sentido à vida.

Apesar de estarem em Portugal, esses regressados jamais se enxergam como

\footnotetext{
17 Para a professora e pesquisadora da Universidade de Lisboa, Inocência Mata, “as teorias pós-coloniais pretendem que elas funcionem, como instrumento de análise de relações de hegemonia e desvelamento da colonialidade do saber segundo uma estratégia de resistência a sistemas de conformação da tendência hierarquizante da diferença, como seja, por exemplo, o eurocentrismo" (2014, p. 31).
} 


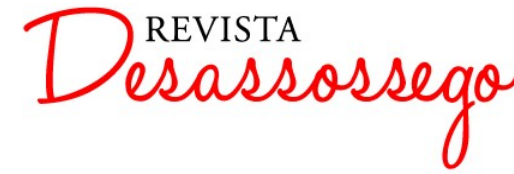

DESASSOSSEGO 20 - parte 2 |JUN/2019 | ISSN 2175-3180

DOI: http://dx.doi.org/10.11606/issn.2175-3180.v11i20p234-250

portugueses metropolitanos, pois a sua gênese encontra-se na África, porém esse território, que outrora fora seu lar, encontra-se perdido. Esse rompimento brusco com o passado torna-se o elemento desencadeador do processo de reincorporação desses indivíduos.

\section{Referências:}

AUERBACH, Erich. Mimesis: a representação da realidade na literatura ocidental. São Paulo: Perspectiva, 1971.

BARTHES, Roland. O Rumor da língua. São Paulo: Martins Fontes, 2004.

BURKE, Peter. A Revolução francesa da historiografia: a Escola dos Annales (1929-1989). São Paulo: Ed. UNESP, 1992.

FIGUEIREDO, Isabela. Caderno de memórias coloniais. 5. ed. Coimbra: Angelus Novus, 2011.

GARCIA, Rita. S.O.S. Angola: Os dias da Ponte Aérea. Lisboa: Oficina do Livro, 2011.

GONÇALVES, Leandro Pereira; PAREDES, Marçal de Menezes. Depois dos Cravos: Liberdades e independências. Porto Alegre: EDIPUCRS, 2017.

HALL, Stuart. Da diáspora: Identidades e Mediações Culturais. Minas Gerais: UFMG, 2008.

MENEZES, Solival. Mamma Angola: Sociedade e Economia de um País Nascente. São Paulo: Edusp, 2000.

NETO, Maria da Conceição. Maria do Huambo: Uma vida de "indígena". Colonizaçãa, estatuto jurídico e discriminação racial em Angola (1926-1961). In África: Revista do Centro de Estudos Africanos. São Paulo: USP, 2005, p. 119-127.

PEARCE, Justin. A Guerra Civil em Angola: 1975-2002. Lisboa: Tinta da China, 2017.

REIS, Carlos. O Conhecimento da Literatura: uma Introdução aos Estudos Literários. 2 ed. Porto Alegre: EDIPUCRS, 2013.

RIBEIRO, Antônio Souza; RIBEIRO, Margarita Calafate (Orgs.). Geometrias da Memória: Configurações Pós-coloniais. Porto: Afrontamento, 2016.

SCHUBERT, Joe. 2013. Democratização e consolidação do poder político em Angola no pós-guerra. Disponível em: http://www.scielo.mec.pt/pdf/ri/n37/n37a07.pdf. Acesso em: 03 de junho de 2018.

SECCO, Lincoln. Trinta anos da Revolução dos Cravos. In Revista Adusp, 33 ed. São Paulo: USP. Outubro de 2004. 